\title{
Characteristics of the Macronutrient Content of Compost and Liquid Organic Fertilizer from Agricultural Wastes
}

\author{
Devianti $^{*}$, Purwana Satriyo ${ }^{1}$, Ramayanty Bulan ${ }^{1}$, Dewi Sartika Thamren ${ }^{2}$, Agustami Sitorus ${ }^{3}$ \\ ${ }^{1}$ Department of Agricultural Engineering, Faculty of Agriculture, Syiah Kuala University, Banda Aceh 23111, Indonesia \\ ${ }^{2}$ Department of Civil Engineering, Nusa Putra University, Jawa Barat 43155, Indonesia \\ ${ }^{3}$ Research Center for Appropriate Technology, Indonesian Institute of Sciences (LIPI), Subang 41213, Indonesia
}

Corresponding Author Email: devidharma28@yahoo.co.id

https://doi.org/10.18280/ijdne.160310

Received: 12 April 2021

Accepted: 4 June 2021

\section{Keywords:}

agricultural wastes, appropriate technology, compost, liquid organic fertilizer

\begin{abstract}
Agricultural products have great potential to produce untapped farm-to-table agricultural waste. This can happen because the agricultural products are damaged before they reach consumers and become agricultural waste. Therefore, paper aims to investigate the macronutrient content of the compost and liquid organic fertilizer using agricultural waste as the main ingredient. There are two treatments for making compost, namely the composition of the main ingredients (rice straw + lamtoro, rice straw + corn stalks, and lamtoro + corn stalks) and the composition of the supporting material in the form of livestock manure (cow dung, goat manure, and chicken manure). There are five treatment sources of the main raw materials for making liquid organic fertilizer tested, namely banana peel, papaya peel, pineapple skin, tomato, and cassava peel. Macro parameters in the form of N, P, K, and C content were measured using the Kjeldahl, Bray, AAS, and Walkle and Black methods, respectively. The $\mathrm{C} / \mathrm{N}$ ratio was calculated by comparing the content of $\mathrm{C}$ and $\mathrm{N}$. Furthermore, data were analyzed using statistical parameters in the form of ANOVA and DMRT. Making compost with the main ingredients of agricultural waste and supporting materials from livestock manure has a significant effect on macronutrient content in compost. Apart from that, the production of liquid organic fertilizer with the main ingredient of agricultural waste significantly affects the macronutrient content of liquid organic fertilizer produced.
\end{abstract}

\section{INTRODUCTION}

Farmers have not widely used agricultural organic waste generated from a process of agricultural cultivation. At least from the process of agricultural cultivation, it will have the potential to produce organic waste as much as $30 \%$ of the products it produces. The large potential of agricultural waste, which is not followed by the processing process, can cause environmental pollution and soil degradation [1-3]. In general, Indonesia's land conditions can experience degradation and a decrease in land productivity in various places such as Sumatra [4-6], and Java [7-9]. The causes include an imbalance in nutrient levels in the soil and untreated agricultural waste. In fact, agricultural waste from agricultural land can be used as a regulator of soil nutrient balance if processed properly.

On the other hand, before agricultural products reach consumers, these agricultural products generally stop at the market. In Indonesia, these agricultural products are traded massively in traditional markets. The perishable nature of agricultural products resulting from inappropriate distribution and storage methods is often found in this traditional market. As a result, the damaged agricultural products are not sold and will be thrown away. This has resulted in piles of agricultural product waste and has not been much processed. Based on research by Al Rasyid [10], there is at least 10.28 tonnes/day
(43.38 $\mathrm{m}^{3} /$ day) of waste in traditional markets. In fact, agricultural waste from this market can be used as liquid organic fertilizer [11].

Some researches related to composting, liquid organic fertilizers, and supporting equipment made from agricultural waste has been conducted. Xue et al. [12] conducted a study related to predicting the compost's maturity from fermented agricultural waste through the dynamic trough composting method. Besides, Wu et al. [13] have also tested the addition of Zeolite and Biochar during composting of agricultural waste. Besides, Phibunwatthanawong and Riddech [11] has also conducted research to produce liquid organic fertilizers for hydroponic cultivation. Even Fahrurrozi et al. [14] have tested the use of liquid organic fertilizer for corn cultivation. However, investigations on the use of agricultural waste originating from agricultural land and waste from traditional markets into compost and liquid organic fertilizer have not been reported in depth until now.

Therefore, to provide information on agricultural waste processing, a study on the characteristics of the macronutrient content of compost and liquid organic fertilizer from various agricultural wastes was carried out. This paper presents an analysis of the macronutrient content of compost and liquid organic fertilizer as the main ingredients of agricultural waste originating from agricultural land and traditional markets. 


\section{MATERIAL AND METHOD}

\subsection{The composition of compost and liquid organic fertilizer}

The composition of agricultural waste materials for composting is presented in Table 1. There are two treatments for composting, namely the composition of the main ingredients and the supporting materials' composition. The materials used for compost are rice straw, lamtoro (Leucaena leucocephala), and corn stalks. The combination composition of the main ingredients for composting consists of three levels of treatment, namely rice straw + lamtoro (A), rice straw + corn stalks (B), and lamtoro + corn stalks (C). $750 \mathrm{~g}$ is needed for each of the main ingredients. The composition of the supporting materials used consists of three treatment levels, namely cow dung (1), goat manure (2), and chicken manure (3). Each of these supporting materials is needed as much as $250 \mathrm{~g}$.

Table 1. Compost composition

\begin{tabular}{cc}
\hline Sample & Composition of compost \\
\hline A1B1 & [rice straw + lamtoro] + cow dung \\
A1B2 & [rice straw + lamtoro] + goat manure \\
A1B3 & [rice straw + lamtoro] + chicken manure \\
A2B1 & [rice straw + corn stalks] + cow dung \\
A2B2 & [rice straw + corn stalks] + goat manure \\
A2B3 & [rice straw + corn stalks] + chicken manure \\
A3B1 & [lamtoro + corn stalks] + cow dung \\
A3B2 & [lamtoro + corn stalks] + goat manure \\
A3B3 & [lamtoro + corn stalks] + chicken manure \\
\hline
\end{tabular}

The main ingredients in composting are obtained from the residue harvested on farmers' land in Aceh province. Reduce the material's size using a chopping machine so that the size is smaller than $5 \mathrm{~mm}$ [15]. Stirring the compost using a compost mixer [16] with the addition of $1000 \mathrm{ml}$ of water and $50 \mathrm{ml}$ of effective micro-organisms bio-activators. Fermentation is carried out for 60 days, and a reversal is carried out every five days. Furthermore, the compost is analyzed for its macronutrient content in the laboratory.

The composition of agricultural waste materials for liquid organic fertilizer is presented in Table 2. There are five treatment sources of the main raw materials for liquid organic fertilizer, namely banana peel, papaya skin, pineapple skin, tomato, and cassava skin. Each source of the main raw material is required as much as $240 \mathrm{~g}$. Additional ingredients in coconut water, rice washing water, and palm sugar are required as much as $240 \mathrm{ml}, 240 \mathrm{ml}$, and $40 \mathrm{~g}$, respectively.

Table 2. Liquid organic fertilizer composition

\begin{tabular}{|c|c|}
\hline Sample & Composition of liquid organic fertilizer \\
\hline D1 & $\begin{array}{c}{[\text { banana peel }]+\text { coconut water }+ \text { rice washing water }+} \\
\text { palm sugar }\end{array}$ \\
\hline D2 & $\begin{array}{c}\text { [papaya skin] }+ \text { coconut water }+ \text { rice washing water }+ \\
\text { palm sugar }\end{array}$ \\
\hline D3 & $\begin{array}{c}{[\text { pineapple skin] + coconut water }+ \text { rice washing water }} \\
+ \text { palm sugar }\end{array}$ \\
\hline D4 & $\begin{array}{c}\text { [tomato }+ \text { coconut water }+ \text { rice washing water }+ \text { palm } \\
\text { sugar }\end{array}$ \\
\hline D5 & $\begin{array}{c}{[\text { cassava skin }]+\text { coconut water }+ \text { rice washing water }+} \\
\text { palm sugar }\end{array}$ \\
\hline
\end{tabular}

The main material for liquid organic fertilizer is obtained from the remaining agricultural materials found in traditional markets in Aceh province. The main ingredient is then crushed so that it is obtained in the form of juice. The juice is then filtered so that a liquid without pulp is obtained. Furthermore, the ingredients are mixed with additional ingredients and stirred until evenly distributed. The product that has been mixed evenly is then carried out an anaerobic fermentation process in a container. Fermentation is carried out for 30 days, and stirring is done every five days. Furthermore, liquid organic fertilizer is analyzed for its macronutrient content in the laboratory.

\subsection{Data acquisition}

The total nitrogen $(\mathrm{N})$ content was measured using the Kjeldahl method [17]. The phosphate content $\left(\mathrm{P}_{2} \mathrm{O}_{5}\right)$ was measured using the Bray method [18]. The potassium content $\left(\mathrm{K}_{2} \mathrm{O}\right)$ was measured using the AAS method [19]. Organic-C content was measured using the Walkley and Black method [20]. The $\mathrm{C} / \mathrm{N}$ ratio is calculated by comparing the total nitrogen $(\mathrm{N})$ content with the organic-C content.

\subsection{Data analysis}

Data obtained were processed for mean values and were analyzed for the existing sources of variation amongst composting parameters using Analysis of Variance (ANOVA) in Microsoft Office Excel 2019. A one-way ANOVA was used to separate the means for significant variables between the drying methods. This procedure is used because it enables the two-sample t-test to be generalized to three or more samples. The means were separated by Duncan multiple range test (DMRT) at 5\% significant difference level.

\section{RESULT AND DISCUSSION}

\subsection{Macronutrient content of compost}

Compost made from agricultural waste is presented in Figure 1. Compost produced from agricultural waste in this study is following the SNI-19-7030-2014 standards regarding compost. However, in the sample with a mixture of [Rice straw + Lamtoro] + chicken manure, the organic-C content still did not reach the compost standard required.

The analysis of variance effects of mixing the main ingredients with the supporting materials on the $\mathrm{N}$ content formed in compost is presented in Table 3 . The mixing of the main ingredients of waste from agricultural land has a significant effect on the formation of the $\mathrm{N}$ content in compost. Also, the mixing of supporting materials from livestock manure has a significant effect on forming the $\mathrm{N}$ content in the compost. Even the interaction of the main and supporting materials has a significant effect on the formation of the $\mathrm{N}$ content in compost.

The DMRT test results of the effect of the main ingredients and supporting materials on the $\mathrm{N}$ content of compost are presented in Table 4. In general, it is known that the treatment levels of the main ingredients and supporting materials for compost in producing the $\mathrm{N}$ content are significantly different. However, at the treatment level of the main ingredients rice straw + lamtoro, the treatment level of the supporting materials for cow and goat manure was not significantly different in producing N. It was different from the level of treatment of 
chicken manure, which produced significantly different $\mathrm{N}$ content. This phenomenon shows that the composition of the use of the main material of agricultural waste and supporting materials from livestock manure can produce a standard compost $\mathrm{N}$ content.

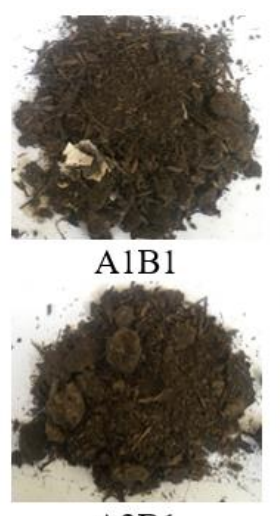

A2B1

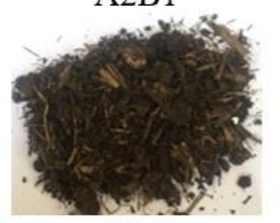

A3B1

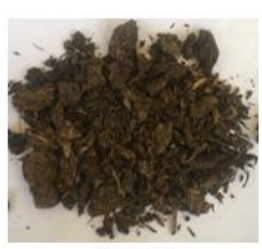

A1B2

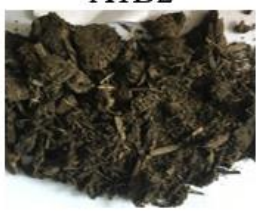

A2B2

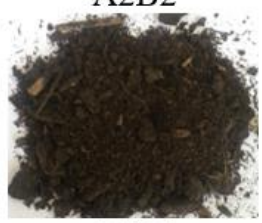

A3B2

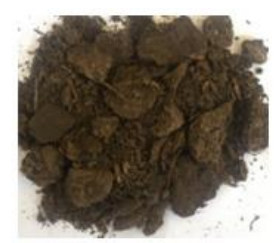

A1B3

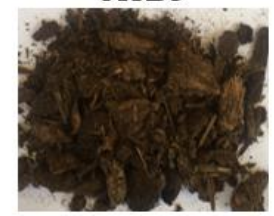

A2B3

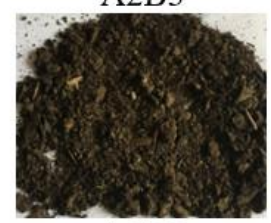

A3B3
Figure 1. Agricultural waste compost

Table 3. ANOVA test of compost $\mathrm{N}$ content

\begin{tabular}{ccccc}
\hline Source & df & $\begin{array}{c}\text { Type III sum } \\
\text { of squares }\end{array}$ & $\begin{array}{c}\text { Mean } \\
\text { square }\end{array}$ & $\begin{array}{c}\text { Sig. } \\
(\boldsymbol{p}<\mathbf{0 . 0 5})\end{array}$ \\
\hline $\begin{array}{c}\text { Main materials } \\
\text { (A) }\end{array}$ & 2 & 0.422 & 0.211 & 0.00 \\
$\begin{array}{c}\text { Supporting } \\
\text { materials (B) }\end{array}$ & 2 & 0.137 & 0.068 & 0.00 \\
A $\times$ B & 4 & 0.104 & 0.026 & 0.00 \\
Error & 18 & 0.002 & & \\
Corrected total & 26 & 0.664 & & \\
\hline
\end{tabular}

Table 4. DMRT test for $\mathrm{N}$ content of compost

\begin{tabular}{cccc}
\hline \multirow{2}{*}{ Main materials (A) } & \multicolumn{3}{c}{ Supporting materials (B) } \\
\cline { 2 - 4 } & $\mathbf{B 1}$ & $\mathbf{B 2}$ & $\mathbf{B 3}$ \\
\hline $\mathrm{A} 1$ & $0.51 \mathrm{aA}$ & $0.50 \mathrm{aA}$ & $0.41 \mathrm{bA}$ \\
$\mathrm{A} 2$ & $0.43 \mathrm{aB}$ & $0.33 \mathrm{bB}$ & $0.37 \mathrm{cB}$ \\
$\mathrm{A} 3$ & $0.83 \mathrm{aC}$ & $0.73 \mathrm{bC}$ & $0.47 \mathrm{cC}$ \\
\hline
\end{tabular}

The numbers followed by the same letter were not significantly different according to the DMRT follow-up test at the 5\% level.

Lowercase letters are read horizontally (row), and uppercase letters are read in a vertical direction (column).

Table 5. ANOVA test of compost $\mathrm{P}$ content

\begin{tabular}{ccccc}
\hline Source & df & $\begin{array}{c}\text { Type III sum } \\
\text { of squares }\end{array}$ & $\begin{array}{c}\text { Mean } \\
\text { square }\end{array}$ & $\begin{array}{c}\text { Sig. } \\
(\boldsymbol{p}<\mathbf{0 . 0 5})\end{array}$ \\
\hline $\begin{array}{c}\text { Main materials } \\
\text { (A) }\end{array}$ & 2 & 0.504 & 0.252 & 0.00 \\
$\begin{array}{c}\text { Supporting } \\
\text { materials (B) }\end{array}$ & 2 & 0.031 & 0.016 & 0.00 \\
A $\times$ B & 4 & 0.123 & 0.031 & 0.00 \\
Error & 18 & 0.002 & & \\
Corrected total & 26 & 0.661 & & \\
\hline
\end{tabular}

The analysis of variance of the effect of mixing the main ingredient with the supporting material on the $\mathrm{P}$ content formed in compost is presented in Table 5. The mixing of the main ingredients of waste from agricultural land has a significant effect on $\mathrm{P}$ content formation in compost. Also, the mixing of additional material from livestock manure has a significant effect on $\mathrm{P}$ content formation in the compost. Even the interaction of the main and supporting materials has a significant effect on the formation of $\mathrm{P}$ content in compost.

The DMRT test of the effect of the main ingredients and supporting materials on the $\mathrm{P}$ content of compost is presented in Table 6. The treatment levels of the main ingredients of rice straw + lamtoro and lamtoro + corn stalks resulted in significantly different $\mathrm{P}$ content for each compost support material treatment level. However, at the treatment level of the main ingredients rice straw + corn stalks, it was found that the $\mathrm{P}$ content in compost was not significantly different for the levels of supporting materials for cow dung and goat manure. Besides, it was also known that the treatment levels of the main ingredients were not significantly different, resulting in $\mathrm{P}$ content at each treatment level of compost support materials. This phenomenon shows that the composition of the use of agricultural waste as the main ingredient and the supporting material of livestock manure can produce a standard $\mathrm{P}$ content of compost.

Table 6. DMRT test for $\mathrm{P}$ content of compost

\begin{tabular}{cccc}
\hline \multirow{2}{*}{ Main materials (A) } & \multicolumn{3}{c}{ Supporting materials (B) } \\
\cline { 2 - 4 } & B1 & B2 & B3 \\
\hline $\mathrm{A} 1$ & $1.49 \mathrm{aA}$ & $1.66 \mathrm{bA}$ & $1.54 \mathrm{cA}$ \\
$\mathrm{A} 2$ & $1.63 \mathrm{aA}$ & $1.62 \mathrm{aA}$ & $1.70 \mathrm{bA}$ \\
$\mathrm{A} 3$ & $1.41 \mathrm{aA}$ & $1.39 \mathrm{bA}$ & $1.18 \mathrm{cA}$ \\
\hline
\end{tabular}

The numbers followed by the same letter were not significantly different according to the DMRT follow-up test at the 5\% level.

Lowercase letters are read horizontally (row), and uppercase letters are read in a vertical direction (column).

The analysis of variance of the effect of mixing the main ingredients with the supporting materials on the $\mathrm{K}$ content formed in compost is presented in Table 7 . The mixing of the main ingredients of waste from agricultural land has a significant effect on the formation of $\mathrm{K}$ content in compost. In addition, mixing additional material from livestock manure also has a significant effect on $\mathrm{K}$ content formation in the compost. Even the interaction of the main and supporting materials has a significant effect on the formation of $\mathrm{K}$ content in compost.

Table 7. ANOVA test of compost K content

\begin{tabular}{ccccc}
\hline Source & df & $\begin{array}{c}\text { Type III sum } \\
\text { of squares }\end{array}$ & $\begin{array}{c}\text { Mean } \\
\text { square }\end{array}$ & $\begin{array}{c}\text { Sig. } \\
(\boldsymbol{p}<\mathbf{0 . 0 5})\end{array}$ \\
\hline $\begin{array}{c}\text { Main materials } \\
\text { (A) }\end{array}$ & 2 & 0.090 & 0.045 & 0.00 \\
$\begin{array}{c}\text { Supporting } \\
\text { materials (B) }\end{array}$ & 2 & 0.006 & 0.003 & 0.00 \\
A $\times$ B & 4 & 0.027 & 0.007 & 0.00 \\
$\quad$ Error & 18 & 0.002 & & \\
Corrected total & 26 & 0.124 & & \\
\hline
\end{tabular}

The DMRT test of the effect of the main ingredients and supporting materials on the $\mathrm{K}$ content of compost is presented in Table 8. The treatment level of the main ingredients of rice straw + lamtoro resulted in significantly different $\mathrm{K}$ content for each compost supporting material. However, the treatment level of the main ingredients rice straw + corn stalks and lamtoro + corn stalks did not produce a $\mathrm{K}$ content that was 
significantly different between the supporting materials for cow dung, and goat manure, and the $\mathrm{K}$ content was significantly different from the use of supporting materials for chicken manure. It was also known that the treatment level of the main ingredients was not significantly different, resulting in $\mathrm{K}$ content at each treatment level of compost support materials. This phenomenon shows that the composition of the use of the main material of agricultural waste and the supporting material of livestock manure can produce a standard $\mathrm{K}$ content of compost.

Table 8. DMRT test for K content of compost

\begin{tabular}{cccc}
\hline \multirow{2}{*}{ Main materials (A) } & \multicolumn{3}{c}{ Supporting materials (B) } \\
\cline { 2 - 4 } & B1 & B2 & B3 \\
\hline A1 & $0.65 \mathrm{aA}$ & $0.72 \mathrm{bA}$ & $0.67 \mathrm{cA}$ \\
A2 & $0.71 \mathrm{aA}$ & $0.70 \mathrm{aA}$ & $0.74 \mathrm{bA}$ \\
A3 & $0.62 \mathrm{aA}$ & $0.61 \mathrm{aA}$ & $0.51 \mathrm{bA}$ \\
\hline
\end{tabular}

The numbers followed by the same letter were not significantly different according to the DMRT follow-up test at the 5\% level.

Lowercase letters are read horizontally (row), and uppercase letters are read in a vertical direction (column)

The analysis of variance of the effect of mixing the main ingredients with the supporting materials on the $\mathrm{C} / \mathrm{N}$ ratio of compost is presented in Table 9. The mixing of the main ingredients of waste from agricultural land has a significant effect on the compost's $\mathrm{C} / \mathrm{N}$ ratio. In addition, the mixing of additives from livestock manure also has a significant effect on the $\mathrm{C} / \mathrm{N}$ ratio formed in the compost. Even the interaction of the main and supporting materials has a significant effect on forming the $\mathrm{C} / \mathrm{N}$ ratio in compost.

Table 9. ANOVA test of compost $\mathrm{C} / \mathrm{N}$ ratio

\begin{tabular}{ccccc}
\hline Source & df & $\begin{array}{c}\text { Type III sum } \\
\text { of squares }\end{array}$ & $\begin{array}{c}\text { Mean } \\
\text { square }\end{array}$ & $\begin{array}{c}\text { Sig. } \\
(\boldsymbol{p}<\mathbf{0 . 0 5})\end{array}$ \\
\hline $\begin{array}{c}\text { Main materials } \\
\text { (A) }\end{array}$ & 2 & 573.955 & 286.978 & 0.00 \\
$\begin{array}{c}\text { Supporting } \\
\text { materials (B) }\end{array}$ & 2 & 70.489 & 35.244 & 0.00 \\
A $\times$ B & 4 & 675.744 & 168.936 & 0.00 \\
Error & 18 & 0.002 & & \\
Corrected total & 26 & 1320.190 & & \\
\hline
\end{tabular}

The DMRT test of the effect of the main and supporting materials on the $\mathrm{C} / \mathrm{N}$ ratio of compost is presented in Table 10 . In general, it is known that the treatment level of compost support in producing the $\mathrm{C} / \mathrm{N}$ ratio is known to be significantly different. However, it differs from the main ingredients' effect, which does not give a real difference to the $\mathrm{C} / \mathrm{N}$ content of the compost ratio produced. This phenomenon shows that the composition of the use of the main material of agricultural waste and the supporting material of livestock manure can produce a standard $\mathrm{K}$ content of compost.

Table 10. DMRT test for $\mathrm{C} / \mathrm{N}$ ratio of compost

\begin{tabular}{cccc}
\hline \multirow{2}{*}{$\begin{array}{c}\text { Main materials } \\
\text { (A) }\end{array}$} & \multicolumn{3}{c}{ Supporting materials (B) } \\
\cline { 2 - 4 } A1 & B1 & B2 & B3 \\
\hline A2 & $30.80 \mathrm{aA}$ & $27.30 \mathrm{bA}$ & $23.68 \mathrm{cA}$ \\
A3 & $13.30 \mathrm{aA}$ & $39.58 \mathrm{bA}$ & $28.14 \mathrm{cA}$ \\
& $13.75 \mathrm{aA}$ & $24.49 \mathrm{bA}$ & $31.30 \mathrm{cA}$ \\
\hline
\end{tabular}

The numbers followed by the same letter were not significantly different according to the DMRT follow-up test at the 5\% level.

Lowercase letters are read horizontally (row), and uppercase letters are read in a vertical direction (column).

\subsection{Macronutrient content of liquid organic fertilizer}

Liquid organic fertilizer made from the main agricultural waste is presented in Figure 2. Analysis of various effects of adding the main raw material on the $\mathrm{N}$ content formed in liquid organic fertilizer is presented in Table 11. The mixing of the main raw materials of agricultural waste from traditional markets is known to affect the formation of $\mathrm{N}$ content significantly. For liquid organic fertilizer. In fact, the $\mathrm{N}$ content obtained from the results of this study was greater than that of Phibunwatthanawong and Riddech [11], which produced liquid organic fertilizer for hydroponic cultivation.

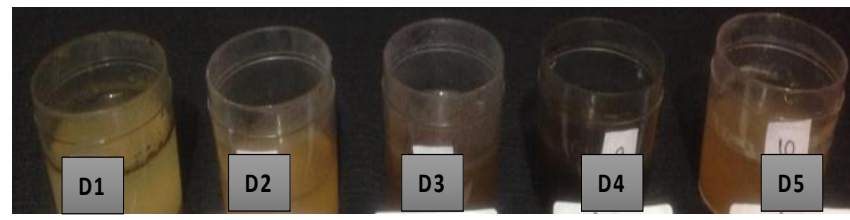

Figure 2. Liquid organic fertilizer from agricultural waste

The analysis of variance of the effect of the addition of the main raw material on the $\mathrm{P}$ content formed in liquid organic fertilizer is presented in Table 12. The mixing of the main raw material for agricultural waste from traditional markets is known to significantly affect the formation of $\mathrm{P}$ content in liquid organic fertilizer. The $\mathrm{P}$ content of liquid organic fertilizer is higher than that of liquid organic fertilizer produced by Phibunwatthanawong and Riddech [11].

Table 11. ANOVA test of liquid organic fertilizer $\mathrm{N}$ content

\begin{tabular}{ccccc}
\hline Source & df & $\begin{array}{c}\text { Type III sum } \\
\text { of squares }\end{array}$ & $\begin{array}{c}\text { Mean } \\
\text { square }\end{array}$ & $\begin{array}{c}\text { Sig. } \\
(\boldsymbol{p}<\mathbf{0 . 0 5})\end{array}$ \\
\hline $\begin{array}{c}\text { Main } \\
\text { materials (D) } \\
\text { Error }\end{array}$ & 4 & 1.622 & 0.405 & 0.000 \\
$\begin{array}{c}\text { Corrected } \\
\text { total }\end{array}$ & 20 & 0.005 & & \\
\hline
\end{tabular}

Table 12. ANOVA test of liquid organic fertilizer $P$ content

\begin{tabular}{ccccc}
\hline Source & df & $\begin{array}{c}\text { Type III sum } \\
\text { of squares }\end{array}$ & $\begin{array}{c}\text { Mean } \\
\text { square }\end{array}$ & $\begin{array}{c}\text { Sig. } \\
(\boldsymbol{p}<\mathbf{0 . 0 5})\end{array}$ \\
\hline $\begin{array}{c}\text { Main } \\
\text { materials (D) } \\
\text { Error }\end{array}$ & 4 & 6.467 & 1.617 & 0.000 \\
$\begin{array}{c}\text { Corrected } \\
\text { total }\end{array}$ & 20 & 0.005 & & \\
\hline
\end{tabular}

Table 13. ANOVA test of liquid organic fertilizer K content

\begin{tabular}{ccccc}
\hline Source & df & $\begin{array}{c}\text { Type III sum } \\
\text { of squares }\end{array}$ & $\begin{array}{c}\text { Mean } \\
\text { square }\end{array}$ & $\begin{array}{c}\text { Sig. }(\boldsymbol{p} \\
\mathbf{< 0 . 0 5})\end{array}$ \\
\hline $\begin{array}{c}\text { Main } \\
\text { materials (D) } \\
\text { Error }\end{array}$ & 4 & 0.029 & 0.007 & 0.000 \\
$\begin{array}{c}\text { Corrected } \\
\text { total }\end{array}$ & 20 & 0.005 & & \\
\hline
\end{tabular}

The analysis of variance of the effect of the addition of the main raw material on the $\mathrm{K}$ content formed in liquid organic fertilizer is presented in Table 13. The mixing of the main raw material for agricultural waste from traditional markets has a significant effect on the formation of $\mathrm{K}$ content in liquid 
organic fertilizer. The $\mathrm{K}$ content in the liquid organic fertilizer obtained by this study is in line with the research conducted by Phibunwatthanawong and Riddech [11].

The DMRT test of the effect of the main ingredients in producing liquid organic fertilizer on the $\mathrm{N}, \mathrm{P}$, and $\mathrm{K}$ content is presented in Table 14. In general, it is known that the treatment of the main ingredients of liquid organic fertilizer produces a significantly different $\mathrm{N}$ content. This phenomenon indicates that the composition of the main ingredient of agricultural waste originating from traditional markets can produce a standard $\mathrm{N}$ content of liquid organic fertilizer. The treatment of the main ingredients of liquid organic fertilizer produces a significantly different $\mathrm{P}$ content. This phenomenon indicates that the composition of the main material used for agricultural waste originating from traditional markets can produce a standard $\mathrm{P}$ content of liquid organic fertilizer. The treatment of the main ingredients for the manufacture of liquid organic fertilizer produces a significantly different $\mathrm{K}$ content. However, it is different from the main ingredients of banana and tomato peels, producing the same K content. Likewise, papaya and cassava's main ingredients did not significantly affect the formation of $\mathrm{K}$ content in liquid organic fertilizer. This phenomenon indicates that the composition of the main ingredient of agricultural waste originating from traditional markets can produce a standard $\mathrm{K}$ content of liquid organic fertilizer.

Table 14. DMRT test for NPK content of liquid organic fertilizer

\begin{tabular}{cccc}
\hline Sample & N content $(\%)$ & P content $(\%)$ & K content $(\%)$ \\
\hline D1 & $1.37 \mathrm{a}$ & $2.05 \mathrm{a}$ & $0.08 \mathrm{a}$ \\
D2 & $1.40 \mathrm{~b}$ & $1.73 \mathrm{~b}$ & $0.09 \mathrm{ab}$ \\
D3 & $1.26 \mathrm{c}$ & $2.97 \mathrm{c}$ & $0.17 \mathrm{c}$ \\
D4 & $1.12 \mathrm{~d}$ & $1.48 \mathrm{~d}$ & $0.08 \mathrm{a}$ \\
D5 & $0.70 \mathrm{e}$ & $1.90 \mathrm{e}$ & $0.11 \mathrm{~b}$ \\
\hline
\end{tabular}

Numbers followed by the same letter in row are not significantly different according to the DMRT follow-up test at the 5\% level.

\section{CONCLUSIONS}

An investigation into the macronutrient content of compost and liquid organic fertilizer made from agricultural waste has been carried out. From the statistical analysis of variance, it is known that the addition of main raw materials and additional raw materials has a significant effect on the formation of $\mathrm{N}, \mathrm{P}$, $\mathrm{K}$, and $\mathrm{C} / \mathrm{N}$ ratios from compost. Likewise, the addition of the main raw materials in the manufacture of liquid organic fertilizer has a significant effect on $\mathrm{N}, \mathrm{P}$, and $\mathrm{K}$ formation. In general, the DMRT test also found that the treatment level for the addition of the main and supporting materials in composting was significantly different in forming the macronutrient content of compost and liquid organic fertilizer. This shows that agricultural waste originating from agricultural land and agricultural waste originating from traditional markets can be used as compost or liquid organic fertilizer. However, the macronutrient content that is formed may vary according to the raw material used. The future research direction is to develop equipment to support agricultural waste processing into compost and liquid organic fertilizer.

\section{REFERENCES}

[1] Dai, Y., Sun, Q., Wang, W., Lu, L., Liu, M., Li, J. (2018). Utilizations of agricultural waste as adsorbent for the removal of contaminants: A review. Chemosphere, 211: 235-253.

https://doi.org/10.1016/j.chemosphere.2018.06.179

[2] Obi, F.O., Ugwuishiwu, B.O., Nwakaire, J.N. (2016). Agricultural waste concept, generation, utilization and management. Nigerian Journal of Technology, 35(4): 957-964.

[3] Gervasi, T., Pellizzeri, V., Calabrese, G., Di Bella, G., Cicero, N., Dugo, G. (2018). Production of single cell protein (SCP) from food and agricultural waste by using Saccharomyces cerevisiae. Natural Product Research, 32(6):

648-653. https://doi.org/10.1080/14786419.2017.1332617

[4] Umami, I.M., Kamarudin, K.N., ABE, S.S. (2019). Does soil fertility decline under smallholder rubber farming? The case of a west Sumatran lowland in Indonesia. Japan Agricultural Research Quarterly: JARQ, 53(4): 279-287. https://doi.org/10.6090/jarq.53.279

[5] Guillaume, T., Holtkamp, A.M., Damris, M., Brümmer, B., Kuzyakov, Y. (2016). Soil degradation in oil palm and rubber plantations under land resource scarcity. Agriculture, Ecosystems \& Environment, 232: 110-118. https://doi.org/10.1016/j.agee.2016.07.002

[6] Asnur, P., Thoha, A.S., Elfiati, D. (2019). Mapping of degraded soil properties in Gunung Leuser National Park. Journal of Sylva Indonesiana, 2(2): 70-79. https://doi.org/10.32734/jsi.v2i2.994

[7] Julianto, E.A., Suntoro, W.A., Dewi, W.S. (2018). Graphical approach to assess the soil fertility evaluation model validity for rice (case study: Southern area of Merapi Mountain, Indonesia). In IOP Conference Series: Earth and Environmental Science, 129(1): 012012. https://doi.org/10.1088/1755-1315/129/1/012012

[8] Joko, T., Anggoro, S., Sunoko, H.R., Rachmawati, S. (2017). Pesticides usage in the soil quality degradation potential in Wanasari subdistrict, Brebes, Indonesia. Applied and Environmental Soil Science. https://doi.org/10.1155/2017/5896191

[9] Mujiyo, M., Rahayu, R., Ustiatik, R., Anggrahini, D.S. (2016). Mapping of soil degradation potency in paddy field Wonogiri, Indonesia. Sains Tanah-Journal of Soil Science and Agroclimatology, 13(1): 25-30. http://dx.doi.org/10.15608\%2Fstjssa.v13i1.481

[10] Al Rasyid, H. (2015). Potensi Pemanfaatan Limbah Organik dari Pasar Tradisional di Bandar Lampung Sebagai Bahan Baku Pembuatan Kompos Dan Biogas. Inovasi Pembangunan: Jurnal Kelitbangan, 3(2): 191202.

[11] Phibunwatthanawong, T., Riddech, N. (2019). Liquid organic fertilizer production for growing vegetables under hydroponic condition. International Journal of Recycling of Organic Waste in Agriculture, 8(4): 369380. https://doi.org/10.1007/s40093-019-0257-7

[12] Xue, W., Hu, X., Wei, Z., Mei, X., Chen, X., Xu, Y. (2019). A fast and easy method for predicting agricultural waste compost maturity by image-based deep learning. Bioresource Technology, 290: 121761. https://doi.org/10.1016/j.biortech.2019.121761

[13] Wu, X., Ren, L., Zhang, J., Peng, H. (2020). Effects of zeolite and Biochar addition on ammonia-oxidizing 
bacteria and ammonia-oxidizing Archaea communities during agricultural waste composting. Sustainability, 12(16): 6336. https://doi.org/10.3390/su12166336

[14] Fahrurrozi, F., Muktamar, Z., Dwatmadji, D., Setyowati, N., Sudjatmiko, S., Chozin, M. (2017). Growth and yield responses of three sweet corn (Zea mays L. var. Saccharata) varieties to local-based liquid organic fertilizer. https://doi.org/10.31227/osf.io/tkzcj

[15] Bulan, R., Yasar, M., Nata, Y., Sitorus, A. (2019). Design and construction of chopper machine AE02-type for oil palm frond. INMATEH-Agricultural Engineering, 57(1): 165-172.

[16] Bulan, R., Rahmah, R., Hasan, A.R., Sitorus, A. (2019). Design and Construction of oil palm fronds (OPF) compost mixer machine type rotary double helix drum. In 2019 5th International Conference on Computing Engineering and Design (ICCED), pp. 1-4. https://doi.org/10.1109/ICCED46541.2019.9161113

[17] Kirk, P.L. (1950). Kjeldahl method for total nitrogen.
Analytical Chemistry, 22(2): $\quad 354-358$. https://doi.org/10.1021/ac60038a038

[18] Sarr, P.S., Khouma, M., Sene, M., Guisse, A., Badiane, A.N., Yamakawa, T. (2009). Effect of natural phosphate rock enhanced compost on Pearl Millet-Cowpea cropping Systems. Journal of the Faculty of AgricultureKyushu University (Japan), 54(1): 29-35. https://doi.org/10.1017/S0021859608008150

[19] Lynn, T.M., Win, H.S., Kyaw, E.P., Latt, Z.K., Yu, S. (2013). Characterization of phosphate solubilizing and potassium decomposing strains and study on their effects on tomato cultivation. International Journal of Innovation and Applied Studies, 3(4): 959-966.

[20] Angelova, V.R., Akova, V.I., Ivanov, K.I., Licheva, P.A. (2014). Comparative study of titimetric methods for determination of organic carbon in soils, compost and sludge. Journal of International Scientific Publications: Ecology and Safety, 8: 430-440. https://www.scientificpublications.net/en/article/1000115/. 